\title{
The Effects of Vasectomy on Epididymal Morphology and Sperm Parameters in Adult Male Balb/c mice
}

\author{
Efectos de la Vasectomía sobre la Morfología del Epidídimo y \\ los Parámetros Espermáticos en Ratones Balb/c Adultos
}

Javad Amini Mahabadi*; Hossein Nikzad*; Aliakbar Taherian* \& Forouzan Mohammadi*

AMINI, M. J.; NIKZAD, H.; TAHERIAN, A. \& MOHAMMADI, F. The Effects of vasectomy on epididymal morphology and sperm parameters in adult male Balb/c mice. Int. J. Morphol., 31(4):1349-1354, 2013.

SUMMARY: Vasectomy is a common contraceptive procedure in men. The present study is aimed to explore the impact of vasectomy on epididymal morphology and sperm parameters in adult male Balb/c mice. Twenty adult (age: 8 weeks) male Balb/c mice, weighting 20-30 g were used in the experiments. They were divided into 2 groups (vasectomy and sham). The operations were performed under sodium pentobarbital ( $40 \mathrm{mg} / \mathrm{kg}$ body weight, IP) anesthesia via a lower mid-abdominal incision. The left epididymis caput was fixed for histological studies and the right one was used for sperm count and motility. Progressive fast and slow sperm motility were significantly decreased in the vasectomized compared to the sham operation group $(\mathrm{P}<0.05)$ and the number of immotile sperm in the vasectomized group was increased in comparison to control group. Sperm granuloma was seen in $60 \%$ of epididymis after vasectomy. Also, Histological study showed an increase in tubular lumen diameter, interstitial space and infiltration of immune cells in interstitial tissue in vasectomized group. Vasectomy increases histopathological changes in epididymis and decreases the motility of sperm developing a reduction in fertility rates.

KEY WORDS: Vasectomy; Epididymis; Mice; Sperm Motility.

\section{INTRODUCTION}

Vasectomy is a common method for birth control in men that causes several implications as well. However, new surgical techniques could decrease these implications significantly (Lavers et al., 2006).

The epididymis has been shown to be responsible for the sustenance, conservation, transport, maturation, and storage of spermatozoa (Cooper. 1998). Maturation of sperm within the epididymis needs the interaction of sperm with epithelium and luminal fluid of the epididymis (Klinefelter \& Hess, 1998). The epididymis is an important part of male reproduction system. Epididymis secrets a specific fluid from its epithelium that provides an environment for sperms to obtain motility and fertilizing potential (Cooper et al., 1988; Amann et al., 1993). In addition to sperm maturation, the epididymis is involved in the transport, concentration, protection and storage of spermatozoa as well (Soudamani et al., 2005).

Conditions such as vasectomy and likely the reversal procedures including vasovasostomy and vasoepididymostomy can have key effects on epididymal cell functions which could positively or negatively affect sperm maturation (Cornwall. 2009). After vasectomy, epididymal epithelium function may change with time, resulting in poor sperm quality after vasovasostomy (Doiron et al., 2003). After vasectomy in adult rats, sperm content was significantly decreased in caput, corpus, and caudal segments, resulting oligozoospermia (Betancourt-Albrecht \& Cunningham, 2003). Histological studies on testis after vasectomy in men and animals demonstrate a spermatogenic detention at the level of primary spermatocytes, desquamation of immature germ cells, deformity of elongated spermatids and loss of germ cells (Soudamani et al.).

After spermatozoa leave the testis in an immature state, they undergo maturational changes and obtain the potential for a forward motility during transit through caput and corpus epididymides (Singh et al., 2009). Epididymal secretory products supply a microenvironment that is considered vital for the attainment of motility and viability of sperm (Singh et al.). Immature spermatozoa swim poorly or not at all, and mature spermatozoa represent a high degree 
of progressive forward motility (Wong, 2002). The reduced forward motility of spermatozoa acquired from caudal segment of epididymis is in correlation with the clinical observation of asthenozoospermia in vasectomized men (Dinulovic \& Radonjic. 1990). Gatti et al., reported that sperm forward motility is the result of a balance between maturation of the flagellum and prevention of the flagellar machinery that keeps spermatozoa in an immotile state. In a study conducted on rabbits, Kong et al. (2004), found out that vasectomy causes severe spermatogenic damage, which is evident 10 days, 3,6 or 12 months after operation.

The purpose of the present study was to examine the effects of vasectomy on epididymal morphology and sperm parameters in adult male Balb/c mice.

\section{MATERIAL AND METHOD}

Animals. Twenty adult ( 8 weeks old) male Balb/c mice, weighing 20-30 g were used in this experiment. The animals were housed under standard laboratory conditions and fed on pelleted food and water ad libitum. They were divided into 2 groups of ten 10 animals. Rats in one group were bilaterally vasectomized and the other group was shamoperated as controls. Animal experimentation was approved by the Ethical Research Committee of Kashan University of Medical Science.

Surgical procedure. The operations were performed under sodium pentobarbital ( $40 \mathrm{mg} / \mathrm{kg}$ body weight, ip) anesthesia via a lower mid-abdominal incision. The vas deferens on each side was exposed without causing injury to the adherent blood vessels and a double ligature about $0.4 \mathrm{~cm}$ apart was applied using 3-0 silk thread. The portion of the vas between the two ligatures was removed and the incision was then closed in two layers. For sham operation, the same procedure was applied except that the vas deferens was neither ligated nor cut.

Tissue collection. Four months after operation, after recording final body weights, animals were sacrificed by an overdose of ether and the testes and epididymis were dissected out and weighed. In this study, the left caput epididymis were fixed for histological studies in freshly prepared Bouin's fluid, dehydrated in graded ethanol series, cleared in xylene and embedded in paraffin wax. Tissues were sectioned at $5 \mu \mathrm{m}$ and were stained with haematoxylin and eosin.

Sperm parameters. The right caput epididymis was used for sperm count and motility. Spermatozoa were collected in $500 \mathrm{~mL}$ Ham, s F10 by cutting cauda epididymis, and they were allowed to disperse for $30 \mathrm{~min}$ at $37^{\circ} \mathrm{C}$. Sperm concentration was determined with a hematocytometer on a sample of the epididymal sperm suspension. Sperm motility was determined by assessing at least five microscopic fields to classify 100 spermatozoa (¥ 400 magnifications). The motility was estimated by using the basic procedure established for routine human semen analyses and graded fast progressive, slow progressive and no progressive or immotile.

Statistical Analysis. Results are presented as Mean \pm SEM. Data were analyzed for statistical difference by ANOVA and Student's t-test. Values were considered significant at $\mathrm{P}<0.05$.

\section{RESULTS}

All animals maintained a healthy appearance throughout the period of study. No significant differences were found between body weights of the vasectomized animals and control group (with sham operations). The epididymal weight showed a significant increase in vasectomized mice in comparison to the control group (Table I).

Sperm count and motility. Epididymal sperm density in the vasectomy group compared to the control group wasn't different. Progressive fast and slow sperm motility were significantly decreased in the vasectomized group compared to the control group $(\mathrm{P}<0.05)$ and the immotile sperm of the vasectomy group in compared to sham operation group was significantly increased. Histological study showed an increase of tubular lumen diameter and infiltration of immune cells in interstitial tissue in vasectomized group (Figs. 1A and 1B). Also, sperm granuloma was shown in $60 \%$ of epididymal samples of vasectomized group (Fig. 1C).

\section{DISCUSSION}

The purpose of this study was to examine the effect of vasectomy on epididymal morphology and sperm parameters in adult male Balb/c mice.

According to the results of this study, progressive fast and slow sperm motility in vasectomy group was significantly lower than that in control group. These results show that vasectomy in mice leads to early failure of spermatogenesis and reduced sperm motility. This effect of vasectomy has been reported in other studies as well. For example, Ren et al. (2011a), who investigated the effect of short period vasectomy on sperm motility in adult male 

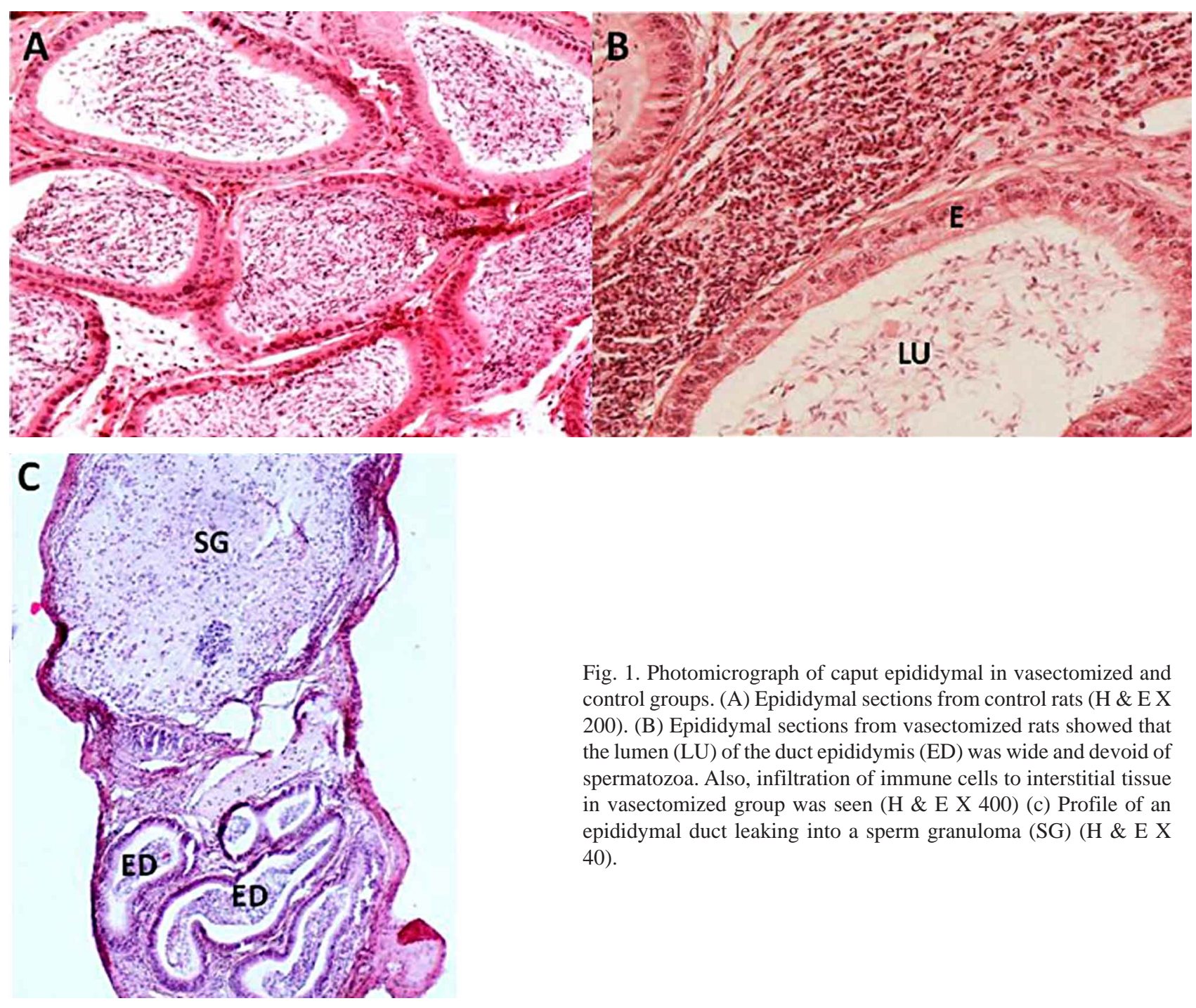

Fig. 1. Photomicrograph of caput epididymal in vasectomized and control groups. (A) Epididymal sections from control rats (H \& E X 200). (B) Epididymal sections from vasectomized rats showed that the lumen (LU) of the duct epididymis (ED) was wide and devoid of spermatozoa. Also, infiltration of immune cells to interstitial tissue in vasectomized group was seen (H \& E X 400) (c) Profile of an epididymal duct leaking into a sperm granuloma (SG) (H \& E X 40).

Table I. The effects of vasectomy on body weight epididymal weight and sperm parameters in adult male mice.

\begin{tabular}{lccc}
\hline Variable & Control group & Vasectomized group & $p$-value \\
\hline Body weight $(\mathrm{g})$ & $46.02 \pm 1.72$ & $45.75 \pm 1.93$ & 0.92 \\
Epididymal weight (mg) & $62 \pm 4$ & $225 \pm 70$ & 0.05 \\
Density of sperm (_106/ml) & $14.9 \pm 1.56$ & $12.3 \pm 1.33$ & 0.22 \\
Progressive fast sperm motility (\%) & $3.9 \pm 0.77$ & $1.00 \pm 0.3$ & 0.002 \\
Progressive slow sperm motility (\%) & $6.00 \pm 1.07$ & $2.00 \pm 0.87$ & 0.009 \\
Immotile sperm (\%) & $5.02 \pm 0.76$ & $9.3 \pm 1.16$ & 0.03 \\
\hline
\end{tabular}

Results expressed in Mean \pm S.E.M. *indicates $\mathrm{P}<0.05, \mathrm{n}=10$.

rats, found that vasectomy can harm spermatogenesis, reducing sperm motility starting from day 60 after vasectomy. Silber et al. (1995), have suggested that in ca- ses of chronically obstructed epididymis, sperm suffer changes related to old age with a significant decrease in motility towards the distal part. 
In our study, another effect of vasectomy on epididymis was its increased weight. A significant increase in epididymal weight was seen in vasectomized mice in comparison to the control group.

Ren et al. (2011a) reported a significant increase of epididymal weight in vasectomized group until 30 days post operation compared with control group as well. However, the weights of epididymis decreased from 30 days post operation compared with control group. Therefore, these studies demonstrated that epididymis weights increases shortly after vasectomy in adult rats. Because, a linear increase in the number of spermatozoa was seen in the epididymis of vasectomized rabbits for up to 6 months that equated closely with estimates of sperm production by the testis (Moore \& Bedford, 1978), it was suggested that the reason for increased weight of epididymis is the early damage to spermatogenesis, decreased sperm motility and accumulation of spermatozoa in the epididymis.

Miller \& Killian demonstrated that the head (caput) of the epididymis of rats with its smaller lumen and larger wall volume (greatest number of columnar epithelial cells), possesses the structural basis for maximizing functional interactions between epididymal tissue and spermatozoa. In contrast, the large lumen and shorter tubular wall of the tail (cauda) of the epididymis supply the structural basis for sperm capacitor (Miller \& Killian, 1987).

The epididymal epithelium is composed of five major cell types of principal, halo, clear, basal, and apical cells. These cells are different in morphological specifications, function, and relative dispensation within the three main regions of the epididymis (Soudamani et al.). Amann et al., reported that the epididymis has an important role in sperm maturation by providing a specific fluid environment secreted from its epithelium that serves as a site for the sperm to obtain motility and fertilizing potential (Amann et al.).

Hooper et al. (1995) suggested that after vasectomy, there is an enhancement in the number of columnar epithelial cells and lymphocytes infiltration in certain regions of the head of the epididymis. These changes causes the rupture of the epithelium and the development of sperm granuloma (Hooper et al., 1995).

The maintenance of a stable internal milieu in the epididymal lumen is adjusted by androgens, which influence the capacity of epididymal epithelium for absorption and secretion.

Légaré et al. (2004), found that poor sperm quality and changes in the function of the epididymal epithelium may occur with time after vasectomy. Also, the epididymal epithelium secretes proteins and other components that create the specific luminal microenvironment required for the maturation of sperm (Lavers et al., 2006).

Several studies reported an impairment of secretary activity of epididymal epithelium and deterrent sperm maturation in vasectomized patients (Dinulovic \& Radonjic; Betancourt-Albrecht \& Cunningham). After vasectomy, the epididymal function may undergo owing to subnormal androgenic status (Singh et al.) and altered epididymidal histoarchitecture (Soudamani et al.).

The acid-base environment of epididymal fluid plays an important role in sperm maturation and development of motility. The in situ PH of epididymis changes significantly, four and eight weeks after bilateral vasectomy in rats. This effect may be the result of subtle alterations in morphology of the epididymis and subsequent impairment of acid-base as well as water transport pathways (Caflisch \& DuBose. 1990).

Singh et al., found that the decreased fertility of vasectomized rats as recognized by in vivo fertility test is probably the result of not only reduced sperm production, but also the abnormal spermatozoa and their impaired forward motility, that makes them incapable of fertilizing the ova. The last specific feature of vasectomized epididymis was sperm granuloma that was seen in $60 \%$ of epididymis in our study. The sperm granuloma has been seen in several other studies as well.

McDonald et al. (1996), reported that vasectomy leads to a mixture of tubular dilatation and single or multiple sperm granuloma formation. Flickinger et al. (1997) have recorded inflammatory reaction after vasectomy, determined by infiltrating macrophages and helper $\mathrm{T}$ lymphocytes all over the epididymis. These cells are penetrated into the epididymis epithelium from the circulation system.

In a survey on the effects of chronic vasectomy in laboratory animals (hamster, rat and monkey) a rapid formation of sperm granulomas in nearly all cases, either at the site of ligation on the vas deferens or in the tail of epididymis was reported (Ren et al., 2011b). Alexander \& Anderson (1979), found that the presence of immunocompetent cells in different parts of the epididymis is important because an individual is capable of mounting an immune response to his own spermatozoa. Also, this researchers showed that antisperm antibodies frequently developed after vasectomy. Thus, probably differences in dispensations of epididymis T lymphocytes and macrophages are not responsible for the greater sensitivity of the immunologic responses to sperm antigens after vasectomy in the Lewis rat (Flickinger et al., 1997). 
One possible explanation for the formation of sperm granuloma in epididymis is that infiltration of $\mathrm{T}$ lymphocytes and macrophages into epididymis beside sperms can form sperm granuloma. Caldwell et al. (1996), reported that Sperm granulomas that have been observed after vasectomy in a number of species are considered as a chronic inflammatory wounds where spermatozoa extravase from the reproductive tract. Several reasons for sperm granuloma have been suggested such as an improper vasectomy performance (Mayenco Aguirre et al., 1996), injuries of the testis and epididymis, congenital occlusion of epididymal duct, severe stenosis or occlusion of the genital tract secondary to infected orchitis and epididymitis, or degeneracy of the seminiferous epithelium with aging (Perez-Marin et al., 2006).

Formation of spermatic granuloma after vasectomy may have a protective effect on the testis as this decreases the intraluminal pressure resulting from the continued production of spermatozoa and fluids by the testis (Flickinger et al., 1995). Perez-Marin et al., suggested that different studies on rats have shown that granuloma formation in the caput epididymides occurs as a last event and is associated with degenerative changes in the testis. The presence of numerous granulomas in the epididymis which is a sign of testicular degeneration suggests that epididymal spermatic granulomas did not prevent testicular damage in the dog (Perez-Marin et al.). Flickinger et al. (1990), reported that vasectomized mice that have been immunized with syngeneic testicular spermatogenic cells develop epididymitis without orchitis, suggesting that the epididymis can be primary site of immune reactions following vasectomy (Qu et al., 2010).

Finally, Vasectomy generally causes the formation of sperm antibodies, a response that is believed to be due to sperm retention and an increased intraluminal pressure in the reproductive tract, leading to increased sperm degradation in situ, epithelial rupture, sperm granuloma formation, and exposure of sperm antigens to the immune system, particularly at the vasectomy site (Alexander \& Tung, 1977; Flickinger et al., 1995).

\section{CONCLUSION}

These results shows that although, vasectomy doesn't affect male rat reproductive systems by decreasing sperm motility but causes an increase histopathological changes in epididymis and decreases motility of sperm that overall leads to a reduction in fertility rates.

ACKNOWLEDGMENTS. This study was a part of the project number 8943 approved by research deputy of Kashan University of Medical Sciences and the authors would like to thank the deputy for the financial support.

AMINI, M. J.; NIKZAD, H.; TAHERIAN, A. \& MOHAMMADI, F. Efectos de la vasectomía sobre la morfología del epidídimo y los parámetros espermáticos en ratones Balb/c adultos. Int. J. Morphol., 31(4):1349-1354, 2013.

RESUMEN: La vasectomía es un procedimiento anticonceptivo común en los hombres. El presente estudio tuvo como objetivo explorar el impacto de la vasectomía sobre la morfología del epidídimo y los parámetros espermáticos en ratones macho adultos Balb/c. Fueron utilizados en el estudio 20 ratones adultos (8 semanas de edad), con un peso ponderado de 20-30 g. Se dividieron en 2 grupos (vasectomía y Sham). Las cirugías se realizaron bajo anestesia con pentobarbital sódico (40 mg/kg de peso corporal, IP), con acceso a través de una incisión medio- abdominal inferior. La cabeza del epidídimo izquierdo fue fijada para estudios histológicos y la cabeza del epidídimo derecho se utilizó para el conteo de espermatozoides y evaluar su motilidad. La motilidad progresiva rápida y lenta de los espermatozoides se redujo significativamente en el grupo de ratones vasectomizados en comparación con el grupo Sham ( $<<0,05)$, y el número de espermatozoides inmóviles en el grupo sometido a la vasectomía aumentó. Granuloma espermático se observó en el $60 \%$ de los epidídimos después de la vasectomía. También, el estudio histológico mostró un aumento del diámetro del lumen tubular, espacio intersticial e infiltración de células inmunitarias en el tejido intersticial en el grupo sometido a la vasectomía . La vasectomía aumenta los cambios histopatológicos en el epidídimo y disminuye la motilidad de los espermatozoides, generando una reducción en las tasas de fertilidad .

PALABRAS CLAVE: Vasectomía; Epidídimo; Ratones; Motilidad espermática.

\section{REFERENCES}

Alexander, N. J. \& Anderson, D. J. Vasectomy: consequences of autoimmunity to sperm antigens. Fertil. Steril., 32(3):253-60, 1979.

Alexander, N. J. \& Tung, K. S. Immunological and morphological effects of vasectomy in the rabbit. Anat. Rec., 188(3):339-50, 1977.
Amann, R. P.; Hammerstedt, R. H. \& Veeramachaneni, D. N. The epididymis and sperm maturation: a perspective. Reprod. Fertil. Dev., 5(4):361-81, 1993.

Betancourt-Albrecht, M. \& Cunningham, G. R. Hypogonadism and diabetes. Int. J. Impot. Res., 15(Suppl. 4):S14-20, 2003.

Caflisch, C. R. \& DuBose, T. D. Jr. Effect of vasectomy on in situ pH in rat testis and epididymis. Contraception, 42(5):589-95, 1990. 
Caldwell, J. C.; McGadey, J.; Kerr, R.; Bennett, N. K. \& McDonald, S. W. Cell recruitment to the sperm granuloma which follows vasectomy in the rat. Clin. Anat., 9(5):302-8, 1996.

Cooper, T. Epididymis. In: Neill, J. D. \& Knobil, E. (Eds.), Encyclopedia of Reproduction. Vol. 2. New York, Academic Press, 1998. pp.117.

Cooper, T. G.; Yeung, C. H.; Nashan, D. \& Nieschlag, E. Epididymal markers in human infertility. J. Androl., 9(2):91-101, 1988.

Cornwall, G. A. New insights into epididymal biology and function. Hum. Reprod. Update, 15(2):213-27, 2009.

Dinulovic, D. \& Radonjic, G. Diabetes mellitus/male infertility. Arch. Androl., 25(3):277-93, 1990.

Doiron, K.; Légaré, C.; Saez, F. \& Sullivan, R. Effect of vasectomy on gene expression in the epididymis of cynomolgus monkey. Biol. Reprod., 68(3):781-8, 2003.

Flickinger, C. J.; Bush, L. A.; Howards, S. S. \& Herr, J. C. Distribution of leukocytes in the epithelium and interstitium of four regions of the Lewis rat epididymis. Anat. Rec., 248(3):380-90, 1997.

Flickinger, C. J.; Herr, J. C.; Caloras, D.; Sisak, J. R. \& Howards, S. S. Inflammatory changes in the epididymis after vasectomy in the Lewis rat. Biol. Reprod., 43(1):34-45, 1990.

Flickinger, C. J.; Howards, S. S. \& Herr, J. C. Effects of vasectomy on the epididymis. Microsc. Res. Tech., 30(1):82-100, 1995.

Hooper, P.; Smythe, E.; Richards, R. C.; Howard, C. V.; Lynch, R. V. \& Lewis-Jones, D. I. Total number of immunocompetent cells in the normal rat epididymis and after vasectomy. J. Reprod. Fertil., 104(2):193-8, 1995

Klinefelter, G. \& Hess, R. A. Toxicology of the male excurrent ducts and accessory sex glands. In: Korach, S. K. (Ed.). Reproductive and Developmental Toxicology. New York, Marcel Decker, 1998. pp.553-91.

Kong, L. S.; Huang, A. P.; Deng, X. Z. \& Yang, Z. W. Quantitative (stereological) study of the effects of vasectomy on spermatogenesis in rabbits. J. Anat., 205(2):147-56, 2004

Lavers, A. E.; Swanlund, D. J.; Hunter, B. A.; Tran, M. L.; Pryor, J. L. \& Roberts, K. P. Acute effect of vasectomy on the function of the rat epididymal epithelium and vas deferens. J. Androl., 27(6):826-36, 2006.

Légaré, C.; Verville, N. \& Sullivan, R. Vasectomy influences expression of HE1 but not HE2 and HE5 genes in human epididymis. J. Androl., 25(1):30-43, 2004.

Mayenco Aguirre, A. M.; García Fernandez, P. \& Sanchez Muela, M. Sperm granuloma in the dog: complication of vasectomy. J. Small Anim. Pract., 37(8):392-3, 1996.

McDonald, S. W.; Lockhart, A.; Gormal, D. \& Bennett, N. K. Changes in the testes following vasectomy in the rat. Clin. Anat., 9(5):296301, 1996 .
Miller, R. J. \& Killian, G. J. Morphometric analyses of the epididymis from normal and vasectomized rats. J. Androl., 8(5):279-91, 1987.

Moore, H. D. \& Bedford, J. M. Fate of spermatozoa in the male: 1. Quantitation of sperm accumulation after vasectomy in the rabbit. Biol. Reprod., 18(5):784-90, 1978.

Pérez-Marín, C. C.; López, R.; Domínguez, J. M. \& Zafra, R. Clinical and pathological findings in testis, epididymis, deferens duct and prostate following vasectomy in a dog. Reprod. Domest. Anim., 41(2):169-74, 2006

Qu, L.; Liu, Y.; Baek, J. B. \& Dai, L. Nitrogen-doped graphene as efficient metal-free electrocatalyst for oxygen reduction in fuel cells. ACS Nano, 4(3):1321-6, 2010.

Ren, L.; Weng, Q.; Kishimoto, M.; Watanabe, G.; Jaroenporn, S. \& Taya, K. Effect of short period vasectomy on FSH, LH, inhibin and testosterone secretions, and sperm motility in adult male rats. Exp. Anim., 60(1):47-56, 2011a.

Ren, L.; Weng, Q.; Kishimoto, M.; Watanabe, G.; Jaroenporn, S. \& Taya, $\mathrm{K}$. Effect of short period vasectomy on $\mathrm{FSH}, \mathrm{LH}$, inhibin and testosterone secretions, and sperm motility in adult male rats. Exp. Anim., 60(1):47-56, 2011b.

Silber, S. J.; Devroey, P.; Tournaye, H. \& Van Steirteghem, A. C. Fertilizing capacity of epididymal and testicular sperm using intracytoplasmic sperm injection (ICSI). Reprod. Fertil. Dev., 7(2):281-93, 1995.

Singh, S.; Malini, T.; Rengarajan, S. \& Balasubramanian, K. Impact of experimental diabetes and insulin replacement on epididymal secretory products and sperm maturation in albino rats. J. Cell Biochem., 108(5):1094-101, 2009.

Soudamani, S.; Malini, T. \& Balasubramanian, K. Effects of streptozotocin-diabetes and insulin replacement on the epididymis of prepubertal rats: histological and histomorphometric studies. Endocr. Res., 31(2):81-98, 2005.

Wong, P. D. Y.; Gong, G. X.; Leunh, G. P. H. \& Cheuk, B. L. Y. Formation of the epididymal fluid microenvironment. In: Robaire, B. \& Hinton, T. (Eds.). The epididymis: From molecules to clinical practices. New York, Kluwer Academic/Plenum Publishers, 2002. pp.11930 .

Correspondence to:

Hossein Nikzad

Anatomical Sciences Research Center

Kashan University of Medical Sciences

Kashan

IRAN

Email: nikzad_h@kaums.ac.ir

Received: 09-04-2013

Accepted: 24-09-2013 